\title{
Agar and pomegranate seed oil used in a biodegradable coating composition for Formosa papaya
}

\author{
Fabricio Alves de MORAIS ${ }^{1 *}$ (D), Railene Hérica Carlos Rocha ARAÚJO², Agda Malany Forte de OLIVEIRA², \\ Kalinny de Araújo ALVES ${ }^{1}$, Raissa Cristina Leandro VITOR ${ }^{1}$, Sinthya Kelly Queiroz MORAIS ${ }^{1}$, \\ Albert Einstein Mathias Medeiros TEODOSIO ${ }^{3}$, Elny Alves ONIAS ${ }^{3}$, Airton Gonçalves de OLIVEIRA ${ }^{4}$
}

\begin{abstract}
The use of biodegradable coatings to conserve fruits and vegetables stands out in the food industry. This study aims to evaluate the postharvest quality of papaya Formosa 'Tainung 01' submitted to different coating formulations, to establish the one that best maintains the postharvest quality. The fruits, distributed in a completely randomized design, received the coatings composed of aqueous solution of agar and pomegranate seed oil in the following compositions (with 6 treatments and 5 replicates): T1: $0.5 \%$ agar and $0.1 \mathrm{~mL} / \mathrm{L}$ oil; T2: $1.0 \%$ agar and $0.2 \mathrm{~mL} / \mathrm{L}$ oil; T3: $1.5 \%$ agar and $0.3 \mathrm{~mL} / \mathrm{L}$ oil; T4: $2.0 \%$ agar and $0.4 \mathrm{~mL} / \mathrm{L}$ of oil; T5: $2.5 \%$ of agar and $0.5 \mathrm{~mL} / \mathrm{L}$ of oil; and T6: Control, uncoated. The experiment lasted ten days packing at $17.5 \pm 0.6{ }^{\circ} \mathrm{C}$ and $55 \pm 3,2 \% \mathrm{RH}$. T4 provided better conservation of the quality attributes in papaya. Fruits in this treatment showed higher vitamin $\mathrm{C}$ content, higher soluble solids and total sugars, and lower titratable acidity, important characteristics for product acceptance. Besides, T4 better conserved the green (external) color of the fruits, while fruits submitted to the other treatments acquired a yellowish coloration.
\end{abstract}

Keywords: Punica granatum L.; postharvest; quality; coating; Carica papaya.

Practical Application: Edible coating based on agar and pomegranate seed oil for postharvest conservation.

\section{Introduction}

The constant changes in the food habits affected by globalization caused the food industry to produce the "instant" foods, increasing the health risks due to the high sugar, sodium and fat contents in these foods. However, the number of conscious consumers seeking healthy food grows exponentially. Thus, to meet this demand, companies sought to produce more and more functional and organic food products that bring health benefits (Stangherlin \& Silva, 2016).

Among functional foods, fruits and vegetables are prominent, as they naturally contain in their composition bioactive compounds such as antioxidants, phenolic compounds, vitamin $\mathrm{C}$ and others. According to Rodrigues (2019), papaya (Carica papaya L.) is a very important fruit, because it has substances with antioxidant power, vitamins, minerals and fibers, which help maintain a healthy diet, besides being one of the most consumed and produced fruits in Brazil.

Another fruit that has attracted the attention of food and pharmaceutical companies is the pomegranate (Punica granatum L.), because it has high levels of phenolic compounds, anthocyanins and other compounds with antioxidant properties (Moreira et al., 2015). Although Brazil is a highlight in world food production, the country also stands out among the countries with the highest food waste in the world - about $30 \%$ of production will end up in the garbage (Teodosio et al., 2018).

With a view to reducing waste, fruit and vegetable producers have sought a number of ways to extend the useful life of these foods, including the use of edible coatings based on natural products, which increase the shelf life of the product.

Among the raw materials proposed for use in this research are pomegranate seed oil and agar. According to Onias et al. (2019), the food industry has considered pomegranate seed oil a very valuable ingredient due to its nutritional properties and potential health benefits. Agar is a carbohydrate that has a high gelling ability making it an important additive ingredient to be used in many industrial applications such as food production, the pharmaceutical industry and microbiology (Fani, 2017).

Thus, this work aims to study different formulations for the composition of a biodegradable and edible coating, and its capacity on the postharvest conservation of Formosa papaya, to establish the one that best suits the quality maintenance and postharvest conservation of the fruit.

${ }^{1}$ Unidade Acadêmica de Tecnologia de Alimentos - UATA, Centro de Ciências e Tecnologia Agroalimentar - CCTA, Universidade Federal de Campina Grande - UFCG, Pombal, PB, Brasil

${ }^{2}$ Unidade Acadêmica de Ciências Agrárias - UAGRA, Centro de Ciências e Tecnologia Agroalimentar - CCTA, Universidade Federal de Campina Grande - UFCG, Pombal, PB, Brasil ${ }^{3}$ Programa de Pós-graduação em Horticultura Tropical, Centro de Ciências e Tecnologia Agroalimentar - CCTA, Universidade Federal de Campina Grande - UFCG, Pombal, PB, Brasil ${ }^{4}$ Unidade Acadêmica de Ciências e Tecnologia Ambiental - UACTA, Centro de Ciências e Tecnologia Agroalimentar - CCTA, Universidade Federal de Campina Grande UFCG, Pombal, PB, Brasil

*Corresponding author: morais.fabricioalves@hotmail.com 


\section{Materials and methods}

\subsection{Acquisition of raw material}

We harvest the fruits in the city of Caraúbas, RN, Brazil, in Sítio Olho D'água da Onça, belonging to the company WG Fruticultura. At the time of harvest, we made a previous selection for uniformity of size and coloration, then we took the papayas to the Fruit Postharvest Technology Laboratory, located in the Center of Science and Technology Agrifood of the Federal University of Campina Grande, Pombal, PB, Brazil campus, where we washed the fruits with $1 \%$ neutral detergent solution, sanitized with $100 \mathrm{ppm}$ sodium hypochlorite solution and placed to dry under ambient conditions of humidity and temperature.

\subsection{Preparation of edible coverings}

For the formulation of the coatings we use agar, brand IMPEX Analytical Reagents, pomegranate seed oil (purchased commercially from the city of Pombal, PB, Brazil) and water. The solutions that formed the biodegradable coatings were: T1: $0.5 \%$ agar plus $0.1 \mathrm{~mL} / \mathrm{L}$ pomegranate seed oil; T2: $1.0 \%$ agar plus $0.2 \mathrm{~mL} / \mathrm{L}$ pomegranate seed oil; T3: $1.5 \%$ agar plus $0.3 \mathrm{~mL} / \mathrm{L}$ pomegranate seed oil; T4: $2.0 \%$ agar plus $0.4 \mathrm{~mL} / \mathrm{L}$ pomegranate seed oil; T5: $2.5 \%$ agar plus $0.5 \mathrm{~mL} / \mathrm{L}$ pomegranate seed oil; T6: Control, without coating.

We prepared the coatings, formulated by solution in water, under constant stirring and heating, to the maximum temperature of $70^{\circ} \mathrm{C}$ and, after cooling to a temperature of 35 to $40^{\circ} \mathrm{C}$, they were used to cover the fruits by immersion in solutions for 30 seconds.

After the immersion, we placed each fruit on a bench, separated by the different coatings received and exposed to an average temperature of $17.5^{\circ} \mathrm{C}$ and $55 \% \mathrm{RH}$. To evaluate the action of the coatings, we leave the fruits under these conditions for a period of ten days.

\subsection{Experimental design and analyzed variables}

We installed the experiment under refrigeration conditions at approximately $17.5 \pm 0.6^{\circ} \mathrm{C}$ and $55 \pm 3.2 \% \mathrm{RH}$, in a completely randomized design with six treatments, five replicates and two fruits per plot. We did an initial sampling of ten fruits that was used for the initial characterization of the quality, at the time of harvest.

After ten days of storage with the coatings, we analyzed the following parameters: Fresh weight loss, bark and pulp color, fruit and pulp firmness, soluble solids (SS, \%), titratable acidity ( $\mathrm{TiA}, \%$ citric acid), vitamin $\mathrm{C}$ (mg/100 g ascorbic acid), $\mathrm{pH}$ and total sugars.

- Fresh weight loss: was measured weighing the fruits in analytical balance at the beginning and end of the experiment. The results were expressed as a percentage, calculated as the difference between the initial and final mass of the fruit;

- Bark and pulp color: were determined by reflectometry in the $\mathrm{L}^{*}, \mathrm{a}^{\star}$ and $\mathrm{b}^{\star}$ system using a Konica Minolta brand reflectometer, model CR-400 Chroma meter. The calibration of the instrument was performed on a standard white board, following the manufacturer's instructions. The factor $\mathrm{L}^{*}$ indicates brightness, $\mathrm{a}^{*}$ is the red/green coordinate ( $+\mathrm{a}$ indicates red and $-\mathrm{a}$ indicates green) and $\mathrm{b}^{*}$ is the yellow/blue coordinate ( + b indicates yellow and $-b$ indicates blue) (Konica Minolta, 2018). To calculate chroma and ohue values are used the $\mathrm{a}^{*}$ and $\mathrm{b}^{*}$ values. Chroma value is given by the formula: $\mathrm{C}=\sqrt{\mathrm{a}^{2}+\mathrm{b}^{2}}$, while the hue angle is calculated using $\left(\mathrm{h}^{\circ}=\operatorname{arctang}\left(\mathrm{a}^{*} / \mathrm{b}^{*}\right)(-1)+90\right)$ for the negative, and for the $a^{*}$ positive $\left(h^{\circ}=90-\operatorname{arctang}\left(a^{*} / b^{*}\right)\right)$;

- Fruit and pulp firmness (N): were determined using a digital penetrometer (Instrutherm, model PTR-300). Measurements were made at two opposite points in the equatorial region of the fruit, after removal of the bark, with a blade of $8 \mathrm{~mm}$, according to Association of Official Analytical Chemists (2006);

- Soluble solids (SS, \%): was determined in the juice by the direct reading in digital refractometer brand Digital Refractometer (Association of Official Analytical Chemists, 2006);

- Titratable acidity (TiA, \% citric acid): was determined by titrating $1 \mathrm{~mL}$ of juice diluted in $50 \mathrm{~mL}$ of distilled water under constant stirring with $0.1 \mathrm{M}$ sodium hydroxide solution, the results were expressed as a percentage of acid citric acid, according to Instituto Adolfo Lutz (2008);

- pH: was determined by direct reading the homogenized pulp using a digital benchtop $\mathrm{pH}$ meter (Mark Digimed DM-22), (Instituto Adolfo Lutz, 2008);

- Vitamin C (mg/100 g ascorbic acid): was determined by titration of $1 \mathrm{~mL}$ of diluted juice to $49 \mathrm{~mL}$ of oxalic acid, titration under constant stirring with DFI (2,6-dichlorophenol indophenol) solution. The results were expressed as $\mathrm{mg} / 100 \mathrm{~g}$ of ascorbic acid, according to Tillman's method (Association of Official Analytical Chemists, 2006);

- Total sugars: was determined by the Antrona method, according to the procedure described by Yemm \& Willis (1954), with modifications.

\subsection{Statistical analysis}

To analyze the differences between the fruits on the day of harvest and after 10 days of treatment, some variables were chosen to performed statistical analysis (analysis of variance ANOVA) and Tukey's test.

We performed the statistical analyzes in the SISVAR 5.6 program using analysis of variance (test F) and Tukey test, at the 5\% probability level (Ferreira, 2011).

\section{Results and discussion}

The results of the physical-chemical analysis of papaya fruits (Formosa 'Tainung 01' variety) at harvest are shown in Table 1.

The fruits analyzed at the time of harvest presented an approximately $1,500 \mathrm{~g}$ average mass. According to Dantas et al. (2015), the fruits were above ideal weight for commercialization (ideal: between 1,000 and 1,300 g). For soluble solids, an average of $11.81 \%$ or ${ }^{\circ}$ Brix was obtained, a value similar to that found by Souza et al. (2014b), which obtained an average of $11.9 \%$ for papayas marketed in Serra Talhada, PE, Brasil, while Dantas et al. (2015) found values greater than $12 \%$ soluble solids for papayas of the same variety. 
The titratable acidity analysis showed an average of $0.34 \%$ citric acid. Results above that observed by Silva (2016), which found an average of approximately $0.1 \%$ in fruits of papaya "Tainung 1 ". Souza et al. (2014a) obtained an average of $0.09 \%$ of citric acid for papayas of the same variety, as well as found by Freitas et al. (2018).

Silva (2019) obtained mean values equal to $82 \mathrm{mg} / 100 \mathrm{~g}$ of vitamin $\mathrm{C}$ for fruits at the beginning of storage time, being found in this study an average of $38.01 \mathrm{mg} / 100 \mathrm{~g}$. Nunes et al. (2017) found mean values above $60 \mathrm{mg} / 100 \mathrm{~g}$ of vitamin C in Formosa papayas coated with cassava starch. The average $\mathrm{pH}$ was 5.21 , which was the same as that found by Viana et al. (2015). However, Nunes et al. (2017) found mean values between 5.34 and 5.44 for papayas of the same variety coated with cassava starch.

The analysis of the external color of the fruits showed a mean for ${ }^{\circ} \mathrm{Hu}^{*}$ equal to $118.3^{\circ}$, a value higher than that found by Silva \& Durigan (2016), who obtained values 84.3 and $107.5^{\circ}$ for Formosa papaya marketed in Boa Vista, RR, Brazil. An average luminosity of 46.4 was observed, while Silva \& Durigan (2016) observed values between 48.8 and 60.1. The mean value obtained for $\mathrm{C}^{\star}$ was 29.6 , besides the fruits presented dark green coloration with medium intensity to the green color.

In the pulp color analyzes, mean values for $\mathrm{h}, \mathrm{C}^{\star}$ and $\mathrm{L}^{\star}$ of $61.1^{\circ}$, 41.7 and 64.3 , respectively, were observed. These values are close to the mean values found by Trigo et al. (2012), corresponding to the color yellow-orange, with a good intensity for the orange coloring, according to the CIELAB system.

The mean values of fruit and pulp firmness were 137.2 and $59.8 \mathrm{~N}$, respectively. Using fruits of the same variety and maturation stage, Souza et al. (2014a) found values of 165.0 and $95.0 \mathrm{~N}$ for fruit and pulp firmness, respectively, characterized these fruits as firmer than the fruits of this study.

Figure 1 shows the results for soluble solids (A), titratable acidity (B), loss of fresh weight (C) and total sugars (D) of fruits submitted to different coatings after 10 days of conditioning.

Table 1. Physical-chemical characteristics of 'Tainung 01' papaya fruits at harvest.

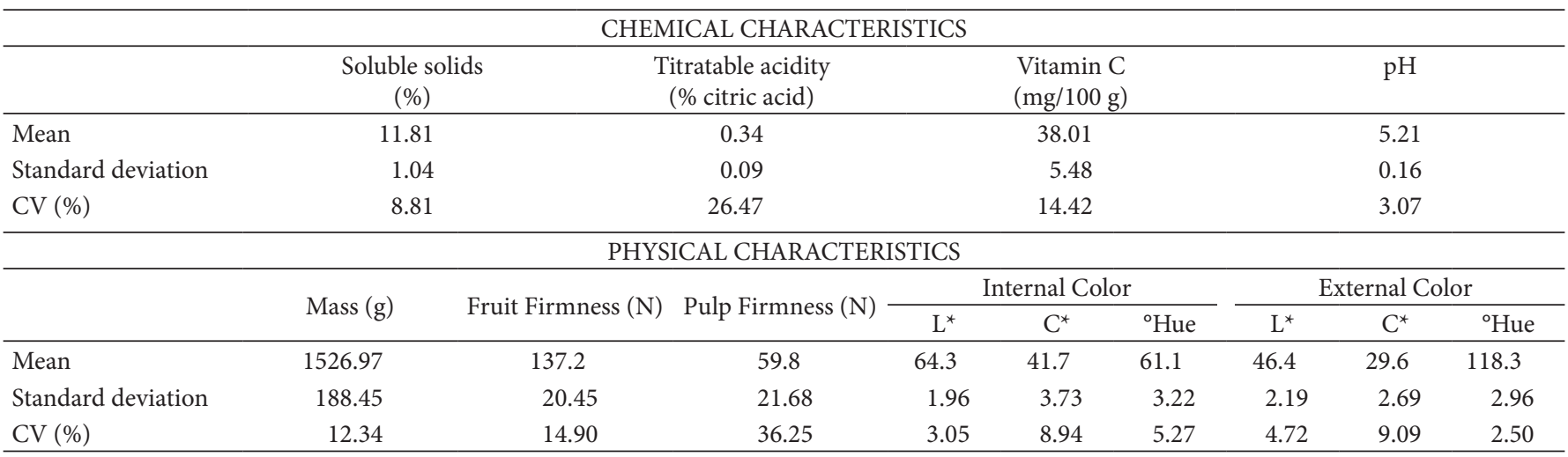

$\mathrm{CV}=$ Coefficient of Variation.

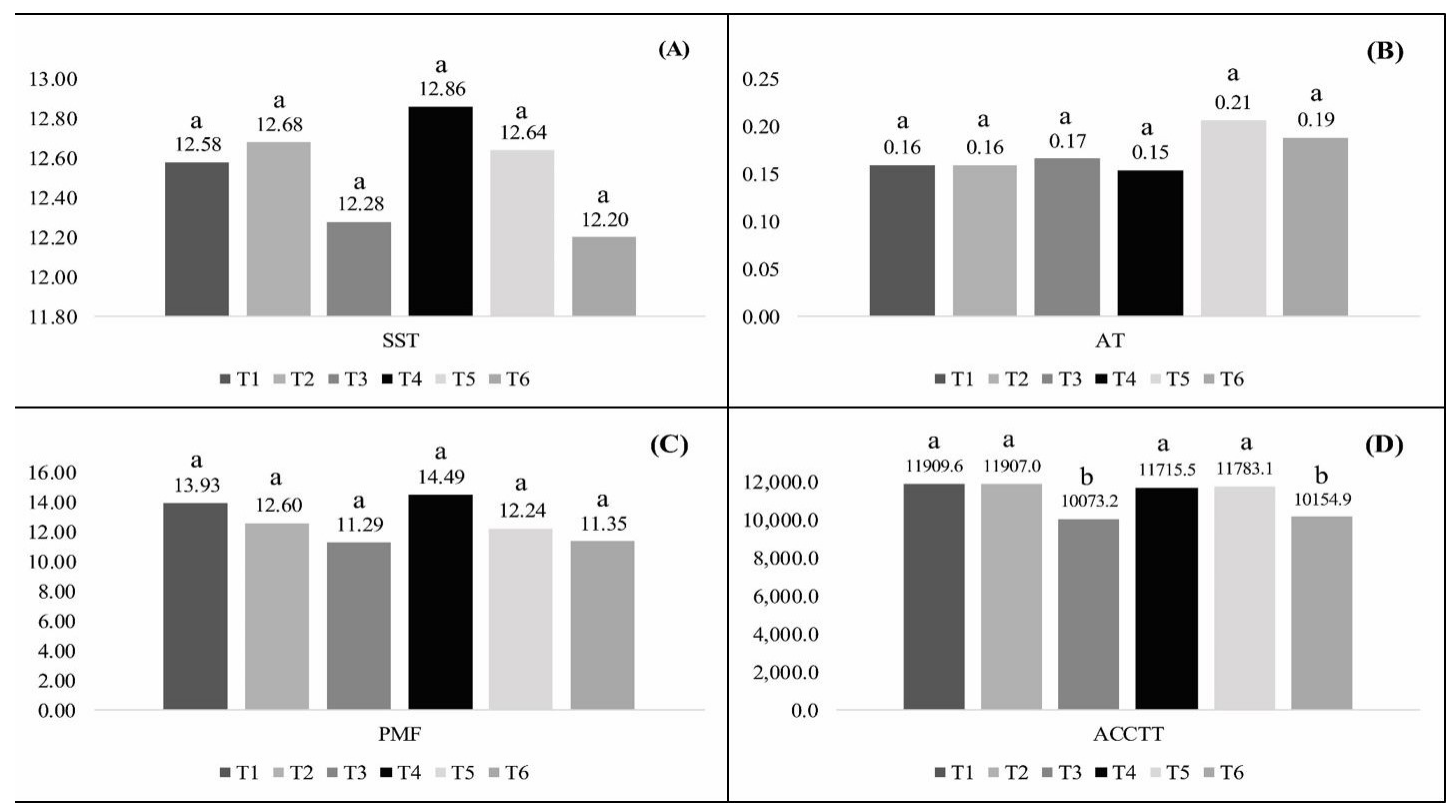

Figure 1. SST = Total Soluble Solids (in \% - A); AT = Titratable Acidity (in \% citric acid - B); PMF = Fresh Weight Loss (in \% - C); ACCTT = Total Sugars (in mg/100 g - D) of papaya Formosa 'Tainung 01' coated with agar and pomegranate seed oil solution after 10 days of storage $\left(17.5 \pm 0.6^{\circ} \mathrm{C}\right.$ and $\left.55 \pm 3.2 \% \mathrm{RH}\right)$. Means followed by the same letter did not differ significantly according to the Tukey test ( $\left.\mathrm{p}<0.05\right)$. 
Total soluble solids and titratable acidity did not differ significantly between treatments according to the Tukey test at the $5 \%$ probability level. The titratable acidity content is higher than the average value found by Souza et al. (2014a), that obtained a content of $0.06 \%$ of citric acid in papaya 'Formosa'. However, Silva (2019) obtained a mean value, at the end of the storage time, of $0.15 \%$ citric acid (similar value to the present study) in papaya fruits of the same variety. The total soluble solids contents found by Barros et al. (2018) in papaya "Formosa" commercialized in Campina Grande, PB, Brazil, was an average value of $12.58 \%$, close to the mean found in this study $(12.54 \%)$. However, Silva (2016) obtained an average value of $10.8 \%$ in “Formosa - Tainung 1" papayas.

The loss of fruit mass did not show a significant difference between the different coatings. In addition, in all coatings the mass loss exceeded the level of 10\%, also observed by Silva (2019), who obtained an average of $13.9 \%$ accumulated mass loss at the end of the storage period. At 10 days of treatment, the papaya presented many bruises, a factor that may have influenced the high rate of mass loss, favoring the senescence of the fruits.

Total sugars contents in the T1, T2, T4 and T5 coatings presented no significant differences, giving the highest results for total sugars. The T3 and T6 treatments provided the lowest values for this variable, differing significantly from the other coatings, but remaining statistically equal. According to Universidade Estadual de Campinas (2011), the total sugar content in papaya fruits of the variety under study should be $11,600 \mathrm{mg} / 100 \mathrm{~g}$, which is close to the content found in T1, T2, T4 and T5 treatments.

Figure 2 shows the results of the analysis of vitamin $\mathrm{C}$ (in $\mathrm{mg} / 100 \mathrm{~g}$ of ascorbic acid), $\mathrm{pH}$ and firmness (pulp and fruit) of the fruits covered by the different treatments.
Vitamin $\mathrm{C}$ and $\mathrm{pH}$ analyzes described above showed a significant difference at $5 \%$ probability level by Tukey's test. $\mathrm{T} 4$ allowed a higher vitamin $\mathrm{C}$ content in relation to the others, suggesting that this is the best treatment for this variable. The overall mean found for ascorbic acid content in papaya fruits was $74.57 \mathrm{mg} / 100 \mathrm{~g}$. According to Universidade Estadual de Campinas (2011), the vitamin C content in papaya of the Formosa variety is $78.5 \mathrm{mg} / 100 \mathrm{~g}$, which is close to the mean value found. The coatings that provided a lower vitamin $\mathrm{C}$ content were $\mathrm{T} 1$ and T6, due to the absence of coating (T6) or the lower concentration of agar and pomegranate seed oil (T1). In their study with cassava starch-based coating, Nunes et al. (2017) found, at 10 days, vitamin $\mathrm{C}$ values between 70 and $80 \mathrm{mg} / 100 \mathrm{~g}$ in papaya of the Formosa variety.

There was little variation of $\mathrm{pH}$ between treatments, with T4 having the highest $\mathrm{pH}$ value, that is, fruits submitted to this treatment are less acid than those submitted to the other treatments. The mean $\mathrm{pH}$ was 5.34, a value close to that found by Nunes et al. (2017), which obtained a mean $\mathrm{pH}$ of 5.3 for papaya fruits of the same cultivar (Formosa - 'Tainung 01'). Already Teodosio et al. (2018), when covering "Golden" papayas with microalgae and pomegranate seed oil, found average $\mathrm{pH}$ values between 4.8 and 5.2.

For the pulp firmness, a significant difference was observed between the treatments, with T6 (control, without coating). The treatments that provided greater firmness in the pulp was T6, and T5 (covering more concentrated in agar and pomegranate seed oil) was the treatment that provided less firmness. Souza et al. (2014a) found a mean of approximately $5.0 \mathrm{~N}$ at 7 days postharvest, which can also be observed by Freitas et al. (2018) when working with the covering of papayas

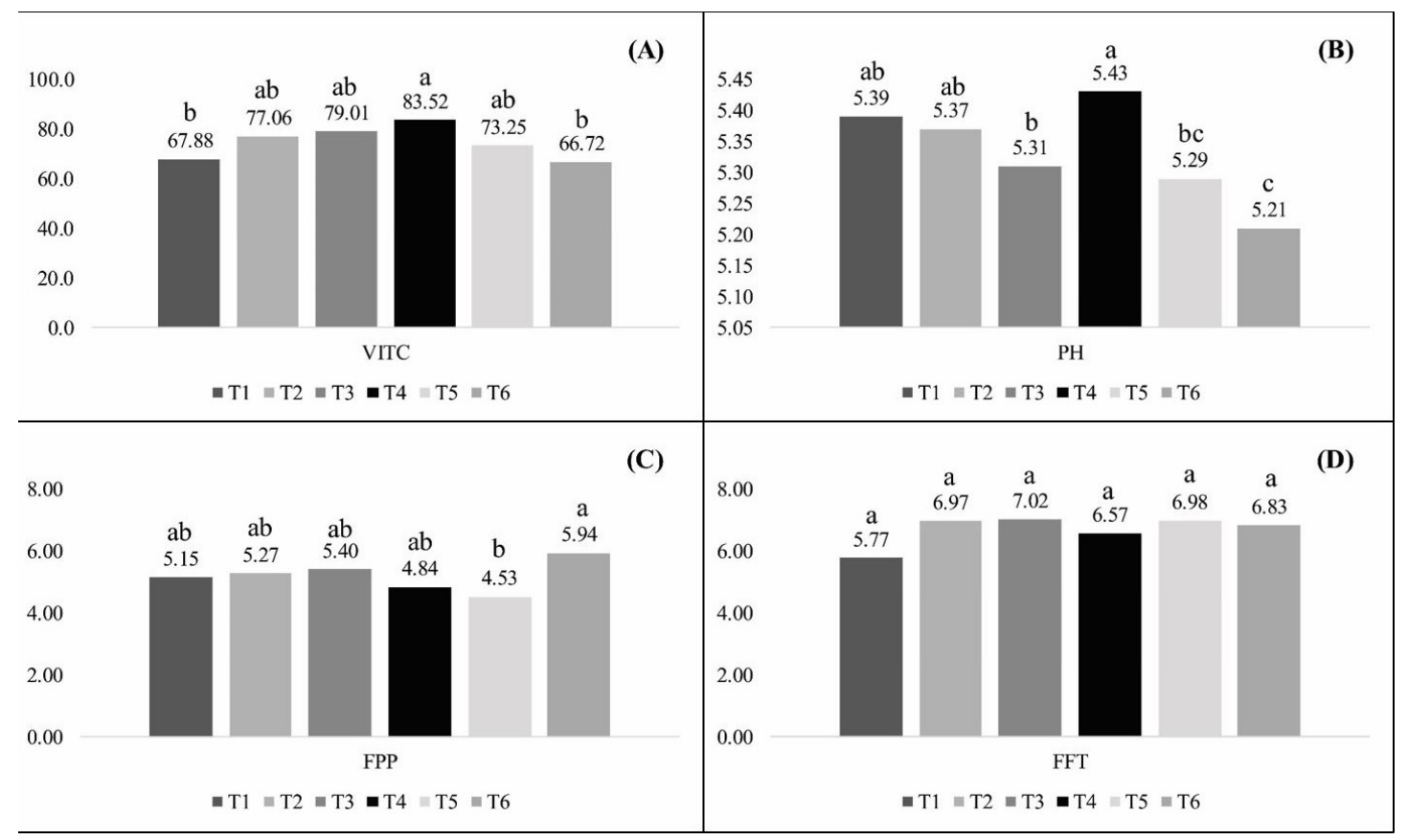

Figure 2. VIT C = Vitamin C analyzes (in mg/100 g - A); pH (B); FPP = Pulp Firmness (in N - C); FFT = fruit firmness (in N - D) of 'Tainung 01 Formosa' papaya coated with agar solution and pomegranate seed oil after 10 days of storage $\left(17.5 \pm 0.6^{\circ} \mathrm{C}\right.$ and $\left.55 \pm 3.2 \%\right)$. Means followed by the same letter did not differ according to the Tukey test $(\mathrm{p}<0.05)$. 
from leaves and fruits of neem, close to the mean found in this study, which was $5.18 \mathrm{~N}$.

There were no significant differences between treatments for fruit firmness. The mean found for this variable was $6.69 \mathrm{~N}$, a value lower than the mean found by Souza et al. (2014a), which was about $20 \mathrm{~N}$, and even lower than the value obtained by Barros et al. (2018), which was about $48 \mathrm{~N}$ for papaya marketed in Campina Grande, PB, Brazil.

Figure 3 shows the results of the external color analysis of the fruits submitted to the coatings.

The variable L (luminosity) showed no significant difference between the treatments, with a mean value of 54.13, providing a medium brightness in the fruits. Souza et al. (2014a) obtained an average of 55.6 for the luminosity, a value close to the value found in this study. Already Barros et al. (2018) observed values for brightness between 36.46 and 40.20. For the variable $\mathrm{C}^{\star}$ (chromaticity), the treatments that allowed a better color intensity were T1, T2, T3 and T6, and there was no significant difference between these treatments according to the Tukey test. Teodosio et al. (2018) observed values between 38 and 48 for chromaticity in "Golden" papayas subjected to microalgae and pomegranate seed oil coating.

T4 treatment had the highest value of ${ }^{\circ}$ Hue color angle, consisting in the yellow-green color. After T4, the treatments that allowed the green color to remain in the fruit peel were T5 and T3, having approximate averages at $100^{\circ}$ hue. The other treatments presented averages in the order of $90^{\circ}$, characterized by a more yellowish color, without the presence of green. At 9 days of storage, Teodosio et al. (2018) found values close to $90^{\circ}$ for the same variable, in "Golden" papayas.

For the internal color (Figure 4 ), the luminosity $\left(\mathrm{L}^{*}\right)$ between the treatments showed no significant difference, that is, the treatments promoted the same intensity of brightness to the fruits. The treatments also did not differ among themselves in the internal color intensity $\left(\mathrm{C}^{*}\right)$, obtaining a good color intensity (approximately 50). This suggests that the fruits remained with the same intensity of color and with a brightness in the range of 50, gray in the luminosity scale. Teodosio et al. (2018) observed values between 55 and 59 for luminosity and 43 and 45 for chromaticity in papayas of the "Golden" variety, being these values similar to those of this study.

The treatments T1 and T2 promoted a purer color for Hue color angle when compared to the other coatings, having a bright orange hue, but close to yellow. However, these treatments did not differ statistically from the T3, T4 and T6 coatings, characterized by an orange color closest to the yellow. The T5 was the lowest value for the hue angle $\left(54.34^{\circ}\right)$, having a more intense orange color, closer to red. Souza et al. (2014a) found higher values (86.3 $3^{\circ}$ at 7 days of storage) in papaya "Formosa - Tainung 1 ".

In order to analyze the efficiency of the coatings it is important to point out some marked differences between the results obtained in the initial characterization of the fruits and the results at the end of the storage period (Table 2).

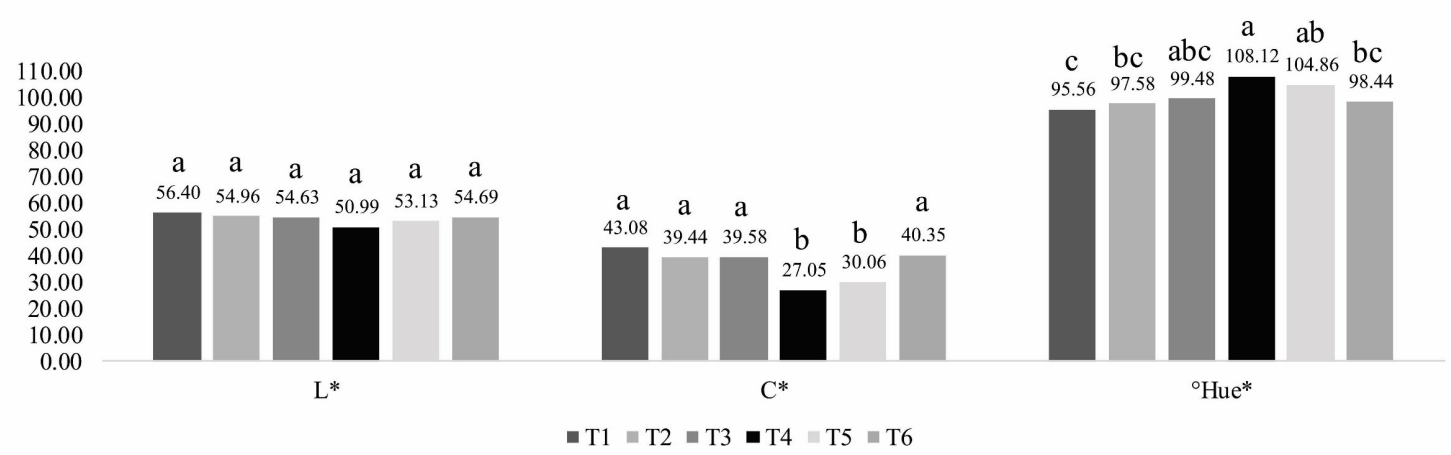

Figure 3. External color analysis of 'Tainung $01^{\prime}$ ' papaya coated with agar and pomegranate seed oil solution at 10 days storage $\left(17.5 \pm 0.6^{\circ} \mathrm{C}\right.$ and $\left.55 \pm 3.2 \%\right)$. Means followed by the same letter did not differ according to the Tukey test $(\mathrm{p}<0.05)$.

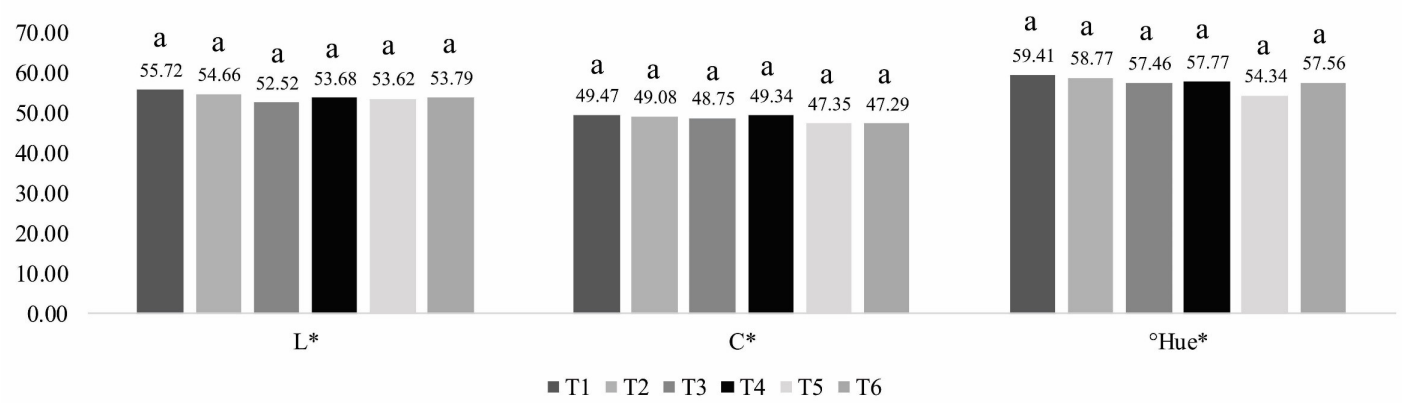

Figure 4. Internal color analysis of 'Tainung 01' papaya coated with solution of agar and pomegranate seed oil at 10 days storage $\left(17.5 \pm 0.6^{\circ} \mathrm{C}\right.$ and $55 \pm 3.2 \%)$. Means followed by the same letter did not differ according to the Tukey test $(\mathrm{p}<0.05)$. 
Table 2. Differences between the beginning and end of the experiment due to the action of the agar and pomegranate seed oil coatings on the “Tainung 01 ” papaya fruits.

\begin{tabular}{ccccccc}
\hline \multirow{2}{*}{ Treatments } & \multicolumn{5}{c}{ CHARACTERISTICS ASSESSED } \\
\cline { 2 - 6 } & $\begin{array}{c}\text { SS } \\
\text { (\%) }\end{array}$ & $\begin{array}{c}\text { AT } \\
(\% \text { citric ac. })\end{array}$ & $\begin{array}{c}\text { Vit. C } \\
(\mathrm{mg} / 100 \mathrm{~g})\end{array}$ & $\begin{array}{c}\text { FFT } \\
(\mathrm{N})\end{array}$ & $\begin{array}{c}\text { ACCTT } \\
(\mathrm{mg} / 100 \mathrm{~g})\end{array}$ & $\begin{array}{c}\text { External }^{\circ} \mathrm{Hue} \\
\text { (1) }\end{array}$ \\
\hline C.I. & $11.8 \mathrm{~b}$ & $0.34 \mathrm{a}$ & $38.0 \mathrm{c}$ & $137.2 \mathrm{a}$ & $10948.8 \mathrm{ab}$ & $118.3 \mathrm{a}$ \\
T1 & $12.6 \mathrm{ab}$ & $0.16 \mathrm{~b}$ & $67.9 \mathrm{~b}$ & $5.8 \mathrm{~b}$ & $11909.6 \mathrm{a}$ & $95.6 \mathrm{~d}$ \\
T2 & $12.7 \mathrm{ab}$ & $0.16 \mathrm{~b}$ & $77.1 \mathrm{ab}$ & $7.0 \mathrm{~b}$ & $11907.0 \mathrm{a}$ & $97.6 \mathrm{~cd}$ \\
T3 & $12.3 \mathrm{ab}$ & $0.17 \mathrm{~b}$ & $79.0 \mathrm{ab}$ & $7.0 \mathrm{~b}$ & $10073.2 \mathrm{~b}$ & $99.5 \mathrm{~cd}$ \\
T4 & $12.9 \mathrm{a}$ & $0.15 \mathrm{~b}$ & $83.5 \mathrm{a}$ & $6.6 \mathrm{~b}$ & $11715.5 \mathrm{a}$ & $108.1 \mathrm{~b}$ \\
T5 & $12.6 \mathrm{ab}$ & $0.21 \mathrm{~b}$ & $73.3 \mathrm{ab}$ & $7.0 \mathrm{~b}$ & $11783.1 \mathrm{a}$ & $104.9 \mathrm{bc}$ \\
T6 & $12.2 \mathrm{ab}$ & $0.19 \mathrm{~b}$ & $66.7 \mathrm{~b}$ & $6.8 \mathrm{~b}$ & $10154.9 \mathrm{~b}$ & $98.4 \mathrm{~cd}$ \\
\hline
\end{tabular}

SS = soluble solids; AT = titratable acidity; Vit. C = Vitamin C; FFT = fruit firmness; ACCTT = total sugars; C.I. = Initial Characterizatin. Means with equal letters in the column did not differ significantly according to the Tukey test $(\mathrm{p}<0.05)$.

There was an increase in soluble solids content during the experiment. Soluble solids can be influenced by many factors, such as environmental conditions. According to Dantas et al. (2015), with the advancement of maturation can occur variations in this content, reaching higher values in the stage of maximum maturation. Although an increase was noted, the initial characterization only differed significantly from T4 coating, treatment with highest content of soluble solids.

There was a significant decrease titratable acidity of the fruits from the day of harvest to the last day of packaging. The drop in acid content may be explained by the increase in soluble solids which are mostly carbohydrates (sugars).

There was a significant increase of ascorbic acid content (vitamin C). T4 treatment obtaining the highest increase for ascorbic acid, and this coating did not differ significantly from the treatments with coatings that had a higher concentration of agar and oil of the seed of pomegranate (T2, T3 and T5). Nunes et al. (2017) report that, unlike other fruits, there is a gradual increase in the vitamin $\mathrm{C}$ content of papaya, which explains the increase.

A significant difference occurred for fruits firmness between the time of harvest and after 10 days of packaging, which can be explained by the constant softening of the fruit tissues during ripening.

We also observed significant difference in total sugar content whose values increased. This result is related to the increase of soluble solids. However, the T3 and T6 treatments decreased total sugars showing a lower final carbohydrate content than the observed in the initial characterization. In the treatments $\mathrm{T} 3$ and T6, the total sugars were between 80 and $90 \%$ of the total soluble solids of the respective treatments, while the other coatings (T1, T2, T4 and T5) obtained a total sugar contents of $90 \%$ of the total soluble solids.

The external hue angle, which refers to the tonality (coloration) of the fruits, was significant different between the initial characterization and the fruits submitted to the coatings. Thus, the fruits went from a dark green coloration to shades of yellow-green and yellow, which occurs due to the degradation of chlorophylls and to the synthesis of carotenoids, due to the ripening phase.

\section{Conclusions}

T4 treatment provided greater conservation of quality attributes in papaya. In this treatment, a higher content of vitamin C, high soluble solids, total sugars and lower titratable acidity were observed, important characteristics for the taste and acceptance by the consumer. $\mathrm{T} 4$ also provided a better conservation of the green coloration of the fruits, while the other treatments gave the appearance of the yellowish coloration in the bark.

\section{References}

Association of Official Analytical Chemists - AOAC. (2006). Official methods of analysis of the Association of Official Analytical Chemists (18th ed.). Washington: AOAC.

Barros, T. F. S., Rios, E. S. C., Maia, L. D. M., Dantas, R. L., \& Silva, S. M. (2018). Qualidade de frutos de cultivares de mamão comercializados em supermercados de Campina Grande - PB. Revista Agropecuária Técnica, 39(2), 129-142. http://dx.doi.org/10.25066/agrotec.v39i2.38109.

Dantas, J. L. L., Lucena, R. S., \& Vilas Boas, S. A. (2015). avaliação agronômica de linhagens e híbridos de mamoeiro. Revista Brasileira de Fruticultura, 37(1), 138-148. http://dx.doi.org/10.1590/01002945-022/14.

Fani, M. (2017). AGAR: gelificante natural com múltiplas aplicações. Revista Food Ingredients Brasil, 19(41), 12-19.

Ferreira, D. F. (2011). Sisvar: um sistema computacional de análise estatística. Ciência e Agrotecnologia, 35(6), 1039-1042. http://dx.doi. org/10.1590/S1413-70542011000600001.

Freitas, R. V. S., Souza, P. A., Senhor, R. F., Moura, C. F. H., \& Costa, F. B. (2018). Post-harvest storage of papaya fruits coated with extracts of leaves and fruits of neem. Revista Caatinga, 31(2), 290-296. http:// dx.doi.org/10.1590/1983-21252018v31n204rc.

Instituto Adolfo Lutz - IAL. (2008). Métodos físico-químicos para análise de alimentos. São Paulo: IAL.

Konica Minolta. (2018). Entendendo o espaço de cor $L^{*} a^{*} b^{*}$. New Jersey. Retrieved from http://sensing.konicaminolta.com.br/2013/11/ entendendo-o-espaco-de-cor-lab/

Moreira, I. S., Rocha, R. H. C., Paiva, E. P., Silva, H. S., \& Sousa, F. A. (2015). Biometria e componentes físico-químicos da romã armazenada sob refrigeração. Pesquisa Agropecuária Tropical, 45(2), 209-215. http://dx.doi.org/10.1590/1983-40632015v4532501.

Nunes, A. C. D., Figueiredo, A. No., Nascimento, I. K. S., Oliveira, F. J. V., \& Mesquita, R. V. C. (2017). Armazenamento de mamão 
'formosa' revestido à base de fécula de mandioca. Revista de Ciências Agrárias, 40(1), 254-263.

Onias, E. A., Araújo, R. H. C. R., Queiroga, T. B., Teodosio, A. E. M. M., Onias, E. A., Ferreira, A. P. N., Rodrigues, M. H. B. S., Santos, A. S., Oliveira, Á. M. F., \& Medeiros, M. L. S. (2019). Coating guava postharvest with the use of starch of tamarind seed and pomegranate seed oil. The Journal of Agricultural Science, 11(1), 313-324. http:// dx.doi.org/10.5539/jas.v11n1p313.

Rodrigues, L. O. (2019). Defensivos alternativos para controle da antracnose e pinta-preta em mamão (Dissertação de mestrado). Universidade Federal do Espírito Santo, Alegre.

Silva, A. R. V., \& Durigan, M. F. B. (2016). Qualidade pós-colheita de mamão formosa (Carica Papaya L.) comercializado em Boa Vista, Roraima. In Anais do $24^{\circ}$ Congresso Brasileiro de Fruticultura. São Luís: Sociedade Brasileira de Fruticultura.

Silva, M. S. (2016). Desempenho de variedades de mamoeiro em clima subtropical do Estado de São Paulo (Dissertação de mestrado). Universidade Estadual Paulista, Botucatu.

Silva, O. P. No. (2019). Ozônio na conservação pós-colheita de mamão (Dissertação de mestrado). Universidade Federal do Amazonas, Manaus.

Souza, A. F., Silva, W. B., Gonçalves, Y. S., Silva, M. G., \& Oliveira, J. G. (2014a). Fisiologia do amadurecimento de mamões de variedades comercializadas no Brasil. Revista Brasileira de Fruticultura, 36(2), 318-328. http://dx.doi.org/10.1590/0100-2945-215/13.

Souza, J. M. A., Ataíde, E. M., \& Silva, M. S. (2014b). Qualidade póscolheita e correlação entre características físicas e químicas de frutos de mamoeiro comercializados em Serra Talhada - PE. Magistra, 26(4), 554-560.

Stangherlin, I. C., \& Silva, T. N. (2016). O mercado de alimentos funcionais: um estudo de caso com uma empresa do ramo. In Anais do XVIII Encontro Internacional sobre Gestão Empresarial e Meio Ambiente (ENGEMA). São Paulo: USP.

Teodosio, A. E. M. M., Araújo, R. H. C. R., Lima, J. F., Onias, E. A., Ferreira, A. P. N., Santos, B. G. F. L., Rodrigues, M. H. B. S., Oliveira, L. M., Oliveira, A. M. F., Medeiros, M. L. S., \& Silva, K. G. (2018). Effect of the biodegradable coatings the base on microalgae and oil of the seed of the pomegranate in the conservation powder-crop of the Papaya 'Golden'. The Journal of Agricultural Science, 10(10), 367-377. http://dx.doi.org/10.5539/jas.v10n10p367.

Trigo, J. M., Albertini, S., Spoto, M. H. F., Sarmento, S. B. S., Reyes, A. E. L., \& Sarriés, G. A. (2012). Efeito de revestimentos comestíveis na conservação de mamões minimamente processados. Brazilian Journal of Food Technology, 15(2), 125-133. http://dx.doi.org/10.1590/ S1981-67232012005000005.

Universidade Estadual de Campinas - UNICAMP, Núcleo de Estudos e Pesquisas em Alimentação - NEPA. (2011). Tabela de composição de alimentos: TACO (4. ed.). Campinas: UNICAMP/NEPA.

Viana, E. S., Reis, R. C., Ronielli Cardoso, S. C. S., Neves, T. T., \& Jesus, J. L. (2015). Avaliação físico-química e sensorial de frutos de genótipos melhorados de mamoeiro. Pesquisa Agropecuária Tropical, 45(3), 297-303. http://dx.doi.org/10.1590/1983-40632015v4535008.

Yemm, E. W., \& Willis, A. J. (1954). The estimation of carbohydrates in plant extracts by anthrone. The Biochemical Journal, 57(3), 508514. PMid:13181867. 